\title{
New records of butterflies and moths from the Czech Republic, and update the Czech Lepidoptera checklist since 2011
}

\author{
Jan Šumpich ${ }^{1 *} \&$ Jan Liška ${ }^{2}$ \\ ${ }^{1}$ Department of Entomology, National Museum, Cirkusová 1740, CZ-193 00 Praha 9 - Horní Počernice, \\ Czech Republic; jansumpich@seznam.cz \\ ${ }^{2}$ Forestry and Game Management Research Institute Jíloviště-Strnady, CZ-156 04 Praha 5 - Zbraslav, \\ Czech Republic; liska@vulhm.cz \\ * corresponding author
}

Šumpich J. \& Liška J. 2018: New records of butterflies and moths from the Czech Republic, and update the Czech Lepidoptera checklist since 2011. - Journal of the National Museum (Prague), Natural History Series 187: 47-64.

\begin{abstract}
Altogether four moth species, namely Agonopterix paraselini Buchner, 2017, A. medelichensis Buchner, 2015, Brachodes pumila (Ochsenheimer, 1808), and Callopistria latreillei (Duponchel, 1827) are reported from the Czech Republic for the first time. Coleophora aleramica Baldizzone \& Stübner, 2007 is reported as a new species for Moravia, and Coleophora bilineatella Zeller, 1849, C. oriolella Zeller, 1849 and Syncopacma albifrontella (Heinemann, 1870) are new species for Bohemia. Historical record of Ischnoscia borreonella (Millière, 1874), unaccepted in previous checklists, is considered possible and included into the species list. Historical records of Plusidia cheiranthi (Tauscher, 1809) which were omitted in recent checklists are now considered reliable. The origin of Dorycnium herbaceum Vill. in Bohemia is commented on the basis of Lepidoptera trophically associated with this plant species.
\end{abstract}

Keywords: Lepidoptera, Dorycnium herbaceum, new records, species list, Czech Republic, Europe, Palearctic Region

Received: July 19, 2018 | Accepted: March 8, 2018 | Issued: December 31, 2018

\section{Introduction}

Concerning Lepidoptera, the Czech Republic belongs among best explored European countries. The history of knowledge of the fauna of Lepidoptera is dated back to the end of the 18th century, and several thousands of various papers concerning this insect order have been published in last c. 220 years. On the basis of those publications and continually increasing interest in the collecting of Lepidoptera, several compendious species lists (mainly the papers by Nickerl) were published already in the second half of the 19th century. The fundamental papers were then published in the first half of the 20th century (Sterneck 1929, Sterneck \& Zimmermann 1931). Whereas among these publications and the subsequent overall list (Laštůvka et al. 1993) more than 60 years passed, the actual effort is to summarize 
the knowledge markedly more often. The last species list was published in 2011 (Laštůvka \& Liška 2011) and its updated version is being prepared currently. The main reason for that is a constantly increasing degree of knowledge of our fauna, and also a higher frequence of nomenclatory changes or the changes in taxonomical status of some species or species groups. The aim of the present paper is to provide an important background material for such update and, besides new records, to summarize the progress in the faunistic knowledge since 2011. Moreover, historical occurrence of selected species, previously not accepted by authors of some species lists for various reasons, is commented. Conversely, some recently published data which need confirmation by subsequent findings (left only with great reservation in the current checklist) are highlighted.

\title{
Material and methods
}

The data on new species for the Bohemian or Moravian-Silesian fauna were obtained partly by collecting activities of the authors and partly by a revision of older museum collections. In order to summarize the current faunistic data, all relevant sources published after 2011 were studied. Nomenclature follows Laštůvka \& Liška (2011).

\author{
Abbreviations: \\ MMBC Moravian Museum, Brno \\ NHMV Natural History Museum, Vienna \\ NMPC National museum, Prague \\ NR Nature Reserve
}

\section{New records and taxa not mentioned in the last version of the Czech species list}

\section{Ischnoscia borreonella (Millière, 1874)}

Published data: Giant Mountains [„Riesengebirge”], Juli (year not stated), Krone leg. (Nickerl 1908).

This published record was accepted by Sterneck \& Zimmermann (1931) in their Prodromus der Schmetterlingsfauna Böhmens, and later also by Novák \& Liška (1997) (with a reservation) and subsequently by Gaedike (2015). However, it was excluded from the last version of the checklist (Laštůvka \& Liška 2011). Regarding its occurrence in Germany, on the basis of historical (although still unrepeated) record we incline to return the species to the Bohemian species list.

\section{Eteobalea serratella (Treitschke, 1833) (fig. 1)}

Material studied: Moravia mer., Lanžhot-Soutok, 8.vii.2017, 1 ઈ, J. Liška leg., det. et coll.

E. serratella was mentioned already in the old checklists by Skala (1912-1913) and Sterneck \& Zimmermann (1933). However, these may concern also other species, still undescribed at that time. All historical records therefore should be revised. Regarding Moravia, beside the record mentioned by Skala (1912-1913), it was published also by Povolný \& Gregor (1948) and Gregor \& Povolný (1949) from Mohelno. The voucher specimens were revised, and they actually belong to the species Eteobalea anonymella (Riedl, 1965) (cf. Šumpich 2017). Similarly, all Bohemian records checked by the authors of this paper always belonged to other Eteobalea species. In spite of its continuous introducing in Bohemian and Moravian Lepidoptera checklists we consider the above mentioned record as the first reliable ones from the Czech Republic. 


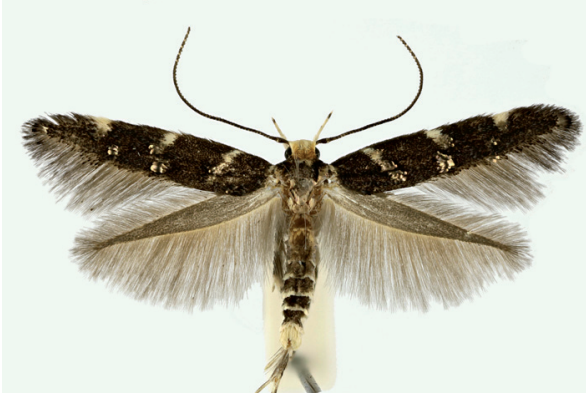

Fig. 1. Eteobalea serratella (Treitschke, 1833), Lanžhot-Soutok $(16 \mathrm{~mm})$.

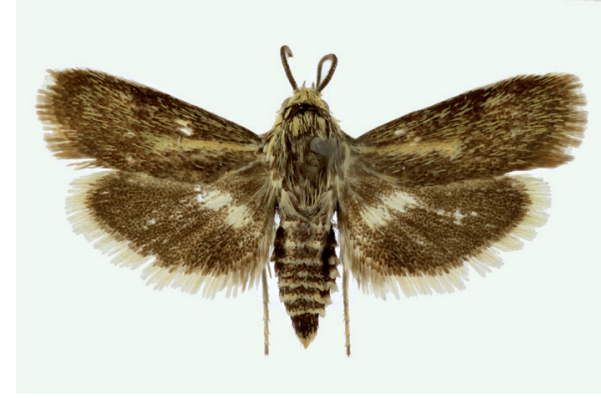

Fig. 2. Brachodes pumila (Ochsenheimer, 1808), Praha (13 mm).

\section{Brachodes pumila (Ochsenheimer, 1808) (fig. 2)}

Material studied: Bohemia centr., Prague, Závist ["Zavist"], Juni (year not stated), 1 ก, 0. Nickerl leg., coll. NMPC.

This record was previously published as Brachodes appendiculata (Esper, 1783) (Nickerl 1908) and later it was accepted also by Sterneck \& Zimmermann (1933). Only recently the voucher specimen was revised and the previous Nickerl's identification corrected. The voucher specimen was placed among the individuals of $B$. appendiculata in the original Nickerl's collection, and in contrast to the majority of other material it is labelled „Zavist | Nickerl". The date of the record was published by Nickerl (1908) and the author also described the habitat as the sunny and dry slopes near the Vltava River. This record, so far unique from the territory of the Czech Republic, is reliable and documents historical occurrence of B. pumila in central Bohemia. Also B. appendiculata has been recorded in Bohemia only once, namely on 5 June 1952 near Srbsko - a village located also in central Bohemia (in the area of the Bohemian Karst) (Krušek \& Soldát 1980). However, the identification of this specimen was not verified so far. Within Czechia this species is sparsely distributed in southern Moravia (e.g. Šumpich 2011a).

\section{Coleophora aleramica Baldizzone \& Stübner, 2007 (fig. 3)}

Material studied: Moravia mer., Lanžhot-Soutok, 5.v.2018, $2 \widehat{\jmath} \widehat{\jmath}$, J. Liška leg., det. et coll.

Recently reported from Bohemia as a new species for the Czech Republic (Liška et al., in press.). Its occurrence is known from France, Italy, Slovakia, Hungary, Austria, Croatia, Montenegro, Macedonia, Bulgaria, Greece, Jordan, and Turkey (Liška et al. 2018). New species for Moravia.

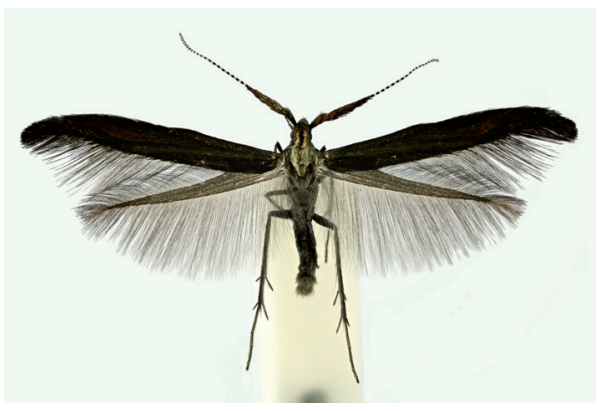

Fig. 3. Coleophora aleramica Baldizzone \& Stübner, 2007, Lanžhot-Soutok (13 mm).

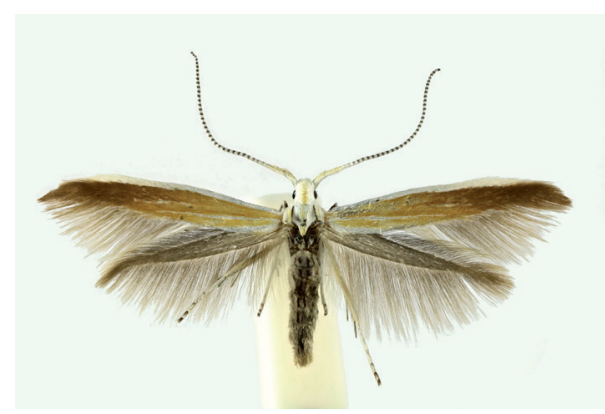

Fig. 4. Coleophora bilineatella Zeller, 1849, Milovice (13 mm). 


\section{Coleophora bilineatella Zeller, 1849 (fig. 4)}

Material studied: Bohemia centr., Milovice - Na Skále (5755), 12.vi.2018, 3 우 , 20.vi.2018, 3 $\widehat{\partial}, 1$ + (all specimens in flight around the tufts of Dorycnium herbaceum Vill.), J. Liška leg., det. et coll.

Very local species in the Czech Republic, recorded so far only in southern Moravia (e.g. Laštůvka \& Liška 2011, Šumpich 2017). In central Europe hitherto not recorded only from Poland (Baldizzone \& van der Wolf 2013). New species for Bohemia.

\section{Coleophora oriolella Zeller, 1849 (fig. 5)}

Material studied: Bohemia centr., Milovice - Na Skále (5755), 12.vi.2018, 1 q, 20.vi.2018, 1 $\widehat{\lambda}, 1$ + (all specimens in flight around the tufts of Dorycnium herbaceum Vill.), J. Liška leg., det. et coll.

Similarly to the previous species, this one is also trophically associated with Dorycnium spp. (but develops also on Lotus spp. and Securigera varia), and was hitherto known only from southern Moravia in the Czech Republic (e.g. Laštůvka \& Liška 2011, Šumpich 2017), recorded also in the Údolí Brtnice NR (Šumpich 2011b). It is known from all neighbouring countries (Baldizzone \& van der Wolf 2013). New species for Bohemia.

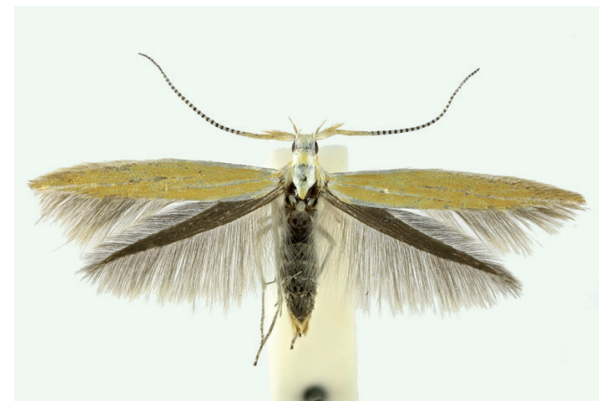

Fig. 5. Coleophora oriolella Zeller, 1849, Milovice (12 mm).

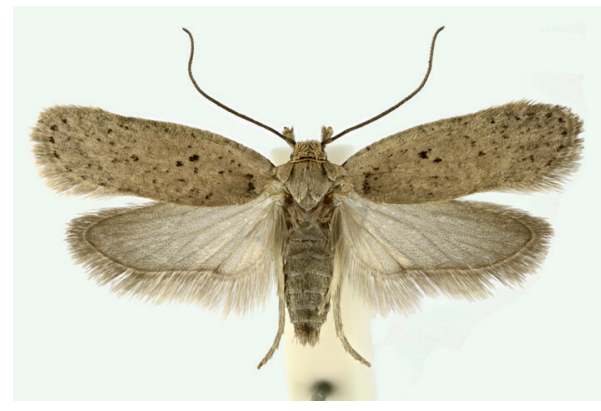

Fig. 6. Agonopterix medelichensis Buchner, 2015, Praha-Radotín (14 mm).

\section{Agonopterix medelichensis Buchner, 2015 (fig. 6)}

Material studied: Bohemia centr., Praha - Prokopské údolí, 29.iv.1992, 10̄, Radotín -

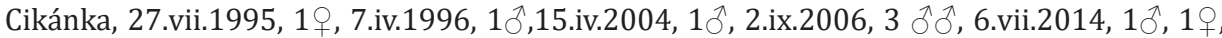
18.viii.2014*, 1f Srbsko, 21.vii.1992, 1ठ, all J. Liška, leg., det. et coll.

Recently described species so far published from Italy, Slovenia, Croatia and Greece (Buchner 2015). It was separated from Agonopterix rotundella (Douglas, 1846) which was repeatedly reported from central Bohemia (Bohemian Karst) and sporadicaly also from Moravia (Laštůvka \& Liška 2011). On the basis of this taxonomic change we report it as new species for the Czech Republic and at the same time we remove A. rotundella from the Czech checklist.

\section{Agonopterix paraselini Buchner, 2017 (fig. 7)}

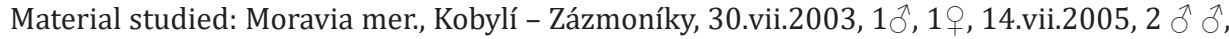
Pavlovské vrchy - Tabulová, 3.viii.2017, 1ठ, 1+, all J. Liška leg., det. et coll., Ječmeniště near Znojmo, 2.vii.2014, 1 ठ̊. J. Skyva leg. et coll., P. Buchner det. (Gp. DEURR 6200).

The species was recently described by a result of the revision of Agonopterix selini group 
of species (Buchner 2017). The Czech vouchers of A. selini (Heinemann, 1870) and A. parilella (Treitschke, 1835) were subsequently revised and the first specimens of A. paraselini were found. A. paraselini has been hitherto recorded in Croatia, France, Greece, Italy, Slovenia, Slovakia and Turkey. New species for the Czech Republic.

\section{Syncopacma albifrontella (Heinemann, 1870) (fig. 8)}

Material studied: Bohemia centr., Milovice - Na Skále (5755), 20.vi.2018, 4 ðð đ̊, 6.vii.2018, 2 $\lesssim \widehat{\jmath}$, J. Liška leg., det. et coll.

In the Czech Republic reported so far only from southern Moravia, mainly the Pálava Hills (Elsner et al. 1999) and the Moravian Karst (Laštůvka et Marek 2002), and also from the southeastern edge of the Bohemian-Moravian Highlands (Dvořák 2017). In central Europe hitherto not recorded only from Poland and Slovenia (Karsholt 2013). The larva develops on Astragalus arenarius L. New species for Bohemia.

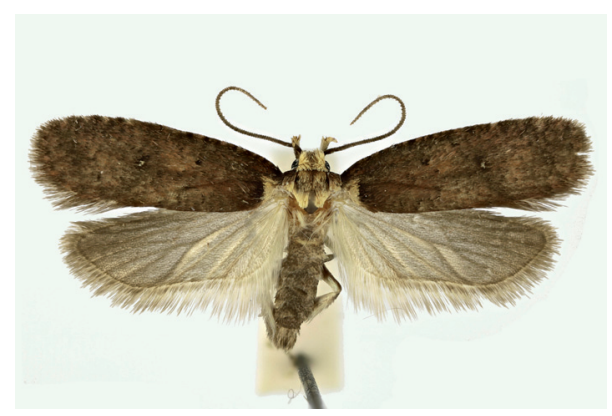

Fig. 7. Agonopterix paraselini Buchner, 2017, Kobylí $(16 \mathrm{~mm})$.

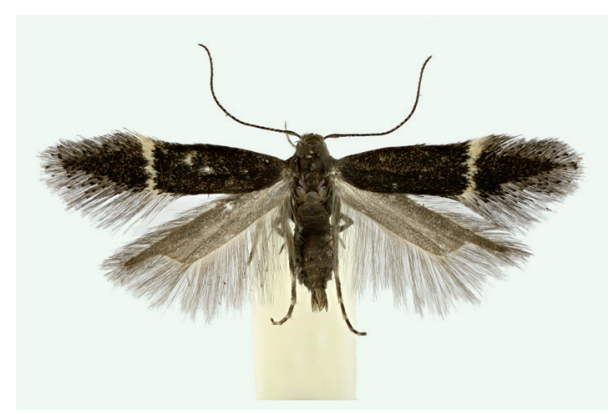

Fig. 8. Syncopacma albifrontella (Heinemann, 1870), Milovice (10 $\mathrm{mm})$.

\section{Limenitis reducta Staudinger, 1901 (figs 9-12)}

Material studied: Bohemia bor., České středohoří [Mittelgebirge], 20.vii.1936, 2 ठో,

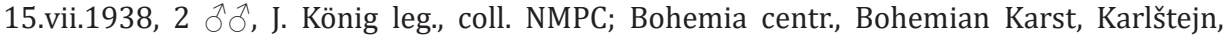
2.vii.1927, 1 §, collector not stated, coll. NMPC.

The species is currently considered extinct in the Czech Republic. Its occurrence in southern and central Moravia in the first half of the 20th century was published by more authors, and Beneš et al. (2002) accepted its historical occurrence in Moravia without a doubt. No record was published from Bohemia so far. However, several Bohemian specimens are deposited in the NMPC. Although the authors are aware of the fact that at that time some entomologists used the locality labels containing their home address instead an exact locality, it must be taken into account that the Bohemian specimens of L. reducta in the NMPC originate from two collections. In proof of the credibility of these records we introduce also the photos of the labels. We consider the historical records from Bohemia possible and thus also reliable, and L. reducta therefore should be listed in the Bohemian checklist.

\section{Plusidia cheiranthi (Tauscher, 1809)}

Published data: Bohemia (without exact locality), 1926 (without exact date) and Cheb (without date) (Goater et al. 2003).

These published records are based on the museum vouchers, both photographed in the monography by Goater et al. (2003). In the neighbouring countries it was recorded in western Poland, and according to Goater et al. (2003) also in north-eastern Germany and 
Slovakia. In Slovakia, its occurrence was published already by Bauer (1927), and later these data were included also to the lists of Slovakian Lepidoptera (e. g. Hrubý 1964, and additional works). This species was removed from Slovakian checklist by Laštůvka (1998) as doubtfull undocumented records. The occurrence in Germany published by Goater et al. (2003) was recently commented by A. Steiner in Gaedike et al. (2017), and he states that $P$. cheranthi actually was never recorded there. From these reasons, it is not listed in the recent German and Slovakian national checklists. However, with respect to the being of Bohemian voucher specimens we cannot so resolutely exclude its occurrence here in the past, and we support its placement to the Bohemian Lepidoptera list as old datum without recent confirmation.

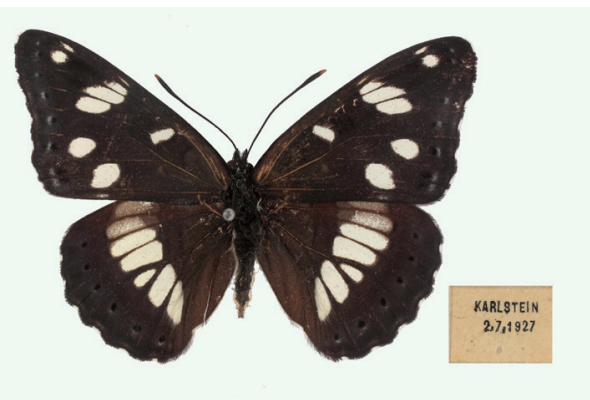

Fig. 9. Limenitis reducta Staudinger, 1901, Karlštejn (52 $\mathrm{mm})$.

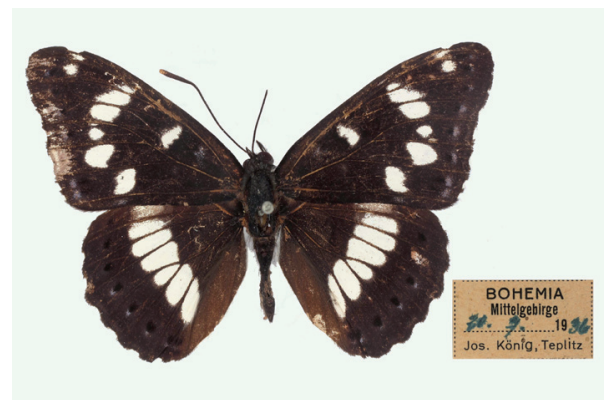

Fig. 11. Limenitis reducta Staudinger, 1901, České středohoří (48 mm).

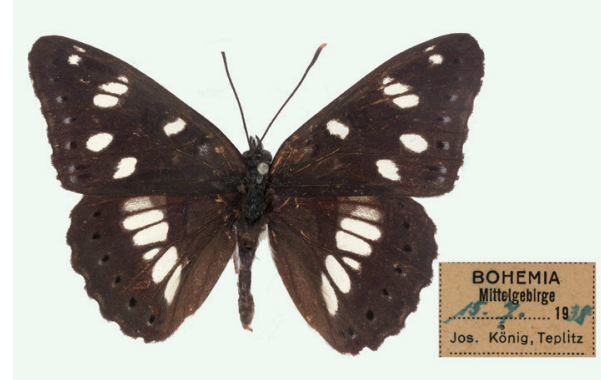

Fig. 10. Limenitis reducta Staudinger, 1901, České středohoří (48 mm).

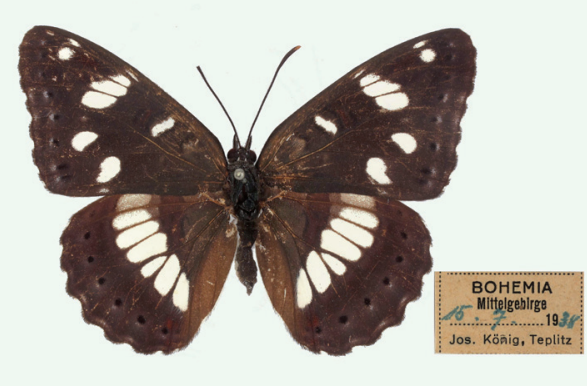

Fig. 12. Limenitis reducta Staudinger, 1901, České středohoří (50 mm).

\section{Callopistria latreillei (Duponchel, 1827) (Figs 13)}

Material studied: Moravia mer., Podyjí National Park, Podmolí env., Liščí skála (rock), 12.vii.2018, 1 ふ, J. Šumpich leg. (NMPC).

A Mediterranean species, outside Europe known from the Canary Islands and northern Africa in the west and to Afghanistan and Turkestan in the east (Fibiger \& Hacker 2007). In central Europe it occurs only in Hungary, Slovenia and Austria (Fibiger \& Skule 2013). However, in Austria it was recorded only in the south, namely in Carinthia (Huemer 2013). C. latreillei is associated with xerotherm, mainly rocky habitats. The larva develops on ferns, predominantly on Asplenium ceterach L. (cf. Fibiger \& Hacker 2007). Considering that within the Czech Republic, A. ceterach recently occurs only in northern and central Bohemia, and at the same time it belongs among critically endangered species (cf. Strnad \& Ekrt 2007), 
the larvae of $C$. latreillei have to develop on other fern species in Podyjí National Park. At the Liščí skála locality, only one specimen was caught by a portable light trap positioned below a high rock wall (figs 14-15) where chasmophytic vegetation of cliffs and screes occurs. Autochtonous occurrence of $C$. latreillei in southern Moravia remains questionable but it is not possible to exclude it. The captured specimen was fresh, and the locality is rather isolated from civilisation. New species for the Czech Republic.

\section{Comments on some species deposited in MMBC and NMPC}

Particular Lepidoptera collections in the NMPC were examined during last four years and some interesting discoveries were made there. Some of them were already published in various papers, the others are still being worked out. The species Rhigognostis schmaltzella (Zetterstedt, 1839), Depressaria bupleurella Heinemann, 1870, and Scrobipalpa hyoscyamella (Stainton, 1869) from the collection of the NMPC were previously overlooked or erroneously identified, and they were listed within the Czech fauna only recently (mostly more than hunderd years after their collecting) (cf. Šumpich et al. 2013, Liška et al. 2015, 2018). Only the first species was confirmed also by recent findings.

A similar situation can be also found in the second largest museum in the Czech Republic - the MMBC. The species Phtheochroa annae Huemer, 1990, Depressaria libanotidella Schläger, 1849, Synaphe antennalis (Fabricius, 1794), and Acrobasis dulcella (Zeller, 1848) were discovered in old collections as new species for Bohemia or the whole Czech Republic (Liška et al. 2008, 2015, 2018). Additional interesting records found in both mentioned museums are reported below.

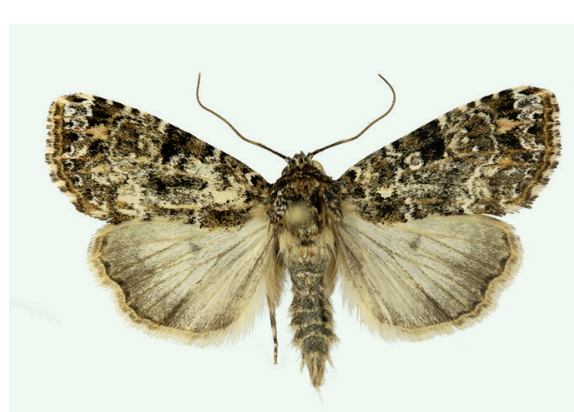

Fig. 13. Callopistria latreillei (Duponchel, 1827), Podmolí, Liščí skála (rock) (24 mm).
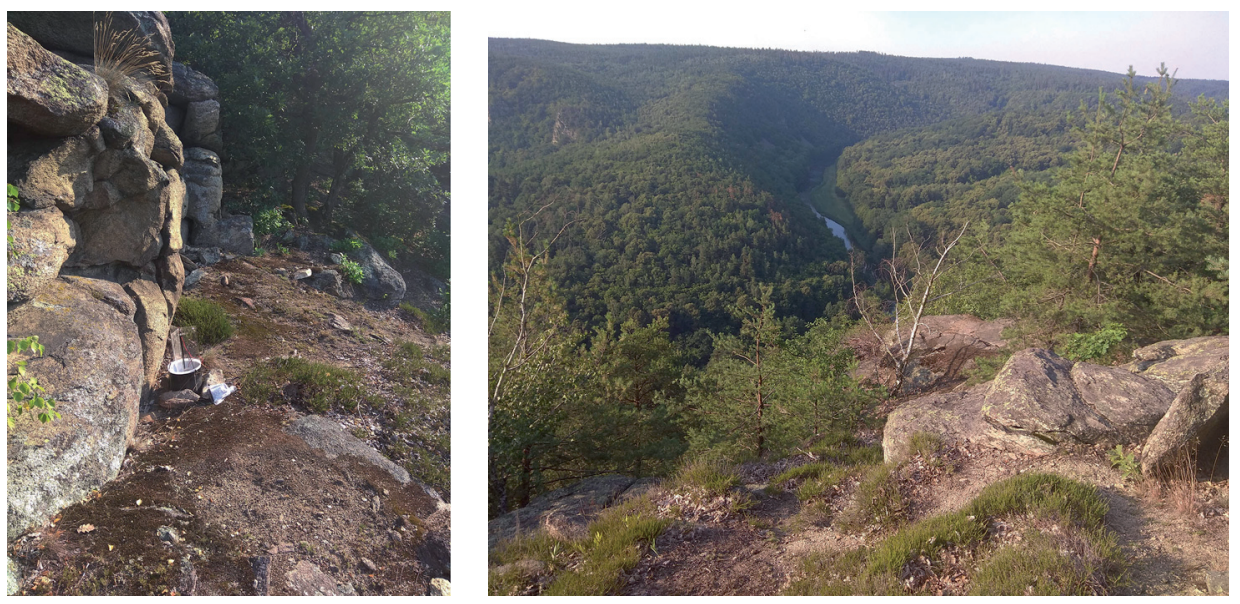

Figs 14-15. Liščí skála (rock) in Podyjí National Park, the habitat of Callopistria latreillei (Duponchel, 1827). Left: portable light trap below the rock. Right: General view of the Dyje river valley from the site where the trap was located. 


\section{Depressaria floridella (Mann, 1864) (fig. 16)}

Material studied: Bohemia centr., Bohemian karst, Prague, Prokopské údolí NR [„Prokop“],

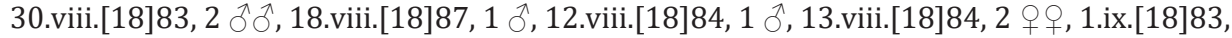
$1 \hat{\jmath}, 1$ ㅇ, 4.ix.[1]882, $1 \hat{\jmath}$ (fig. 16), 21.vi.[18]90, $1 \hat{\jmath}$, 0. Nickerl leg., coll. NMPC.

The species was recently reported as new for Bohemia (Šumpich et al. 2013) and subsequently also for Moravia (Liška et al. 2015). However, a series of 13 specimens of the species is deposited in Nickerl's research collection in the NMPC. Ten specimens ( $7 \hat{\delta} \hat{\sigma}$ and $3 q+$ ) are labelled as „Sct. Prokop“, „St. Prokop“ or „Prokop“ (see the exact data above), three specimens are unlabelled but most likely originating from the same locality. One male from 21 June 1890 was identified and published by O. Nickerl as Depressaria chaerophylli Zeller, 1839 (cf. Nickerl 1908), the others were unsorted as unidentified. Until recently, D. floridella was known only from Turkey (locus typicus) and Greece, now it is known from Spain across central Europe to Ukraine, Russia, and Caucasus (Buchner \& Šumpich, in press). Recently it was collected on more sites of the Bohemian Karst, including the Prokopské údolí NR (Liška 2015).

\section{Megacraspedus albovenatus Junnilainen, 2010 (fig. 17)}

Material studied: Moravia mer., Pouzdřany env., Pouzdřanská step [Pouzdřany steppe], 17.vii.1947, F. Gregor leg., coll. MMBC.

A species described recently from southern Ural. Its occurrence in the Czech Republic was firstly published from Hustopeče in southern Moravia (Vávra et al. 2008, published as $M$. fallax Mann, 1867). Later it was recorded also on other Moravian sites and also in Slovakia (Šumpich et al. 2011, Šumpich \& Skyva 2012). Its formerly overlooked occurrence in central Europe is confirmed by the presented record.

\section{Cydia ilipulana (Walsingham, 1903) (figs 18-19)}

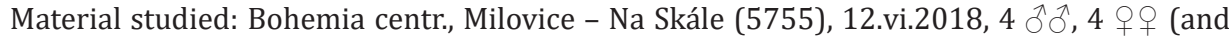
several dozens of specimens observed), J. Liška leg. et det., coll. NMPC, 20.vi.2018, more specimens, J. Liška observ.

To date it was known only from southern Moravia (cf. Šumpich 2017). However, the species was recorded by J. Vávra in Bohemia (the same locality as stated above -Milovice env.) already in the 1990s but published as new species for Bohemia only recently (Liška et al. 2018). The new records confirm its permanent presence at the locality, and also its relation to Dorycnium spp. (cf. Walsingham 1903) in which growths the adults were obligatory observed. Also at other localities it is being observed only in the communities with this plant species (similarly like the related Cydia centralasiae Obratztsov, 1949).

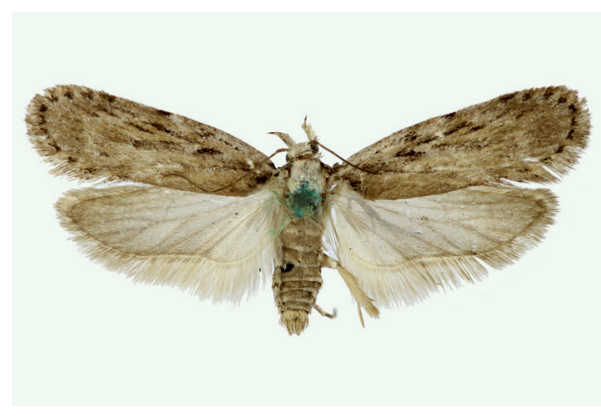

Fig. 16. Depressaria floridella (Mann, 1864), Prague (20 mm).

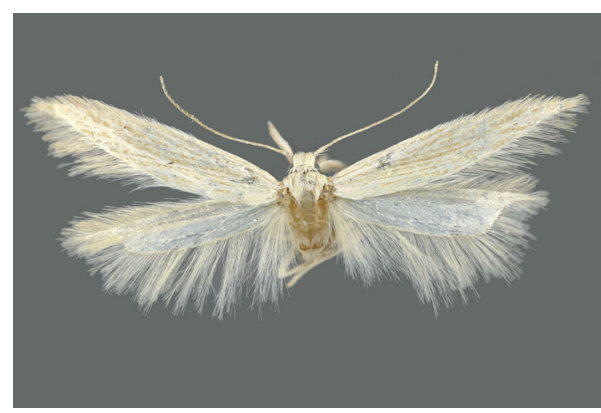

Fig. 17. Megacraspedus albovenatus Junnilainen, 2010, Pouzdřany $(12 \mathrm{~mm})$. 
Material studied: Bohemia bor., Staré Splavy env., Jestřebí [“Thammül” ], 27.vii.1936, 1 ภ, 30.vii.1936, 1 ð, F. Zimmermann leg., coll. NMPC.

The first record of $C$. heringiellus from the Czech Republic was published only recently by Šmpich et al. (2011). However, two older specimens originating from the same locality as the recent finding are deposited in the NMPC, and F. Zimmermann correctly identified them but he already did not manage to publish the records himself, and these remained unnoticed to date. The records are very important from the faunistic view as the locality is placed on the south-western border of currently known distribution of $C$. heringiellus. The locality also represents one of the most important sites for boreal elements in Bohemia.

\section{Eucarta amethystina (Hübner, 1803)}

Material studied: Moravia mer., Valtice env., 23.vi.1970, 1 §, 26.vi.1970, 1 , , Kaftan leg., coll. NMPC.

The species was recently published as new for the Czech Republic from southern Moravia (Liška et al. 2014). However, its already earlier occurrence in the area is confirmed by the above presented record.

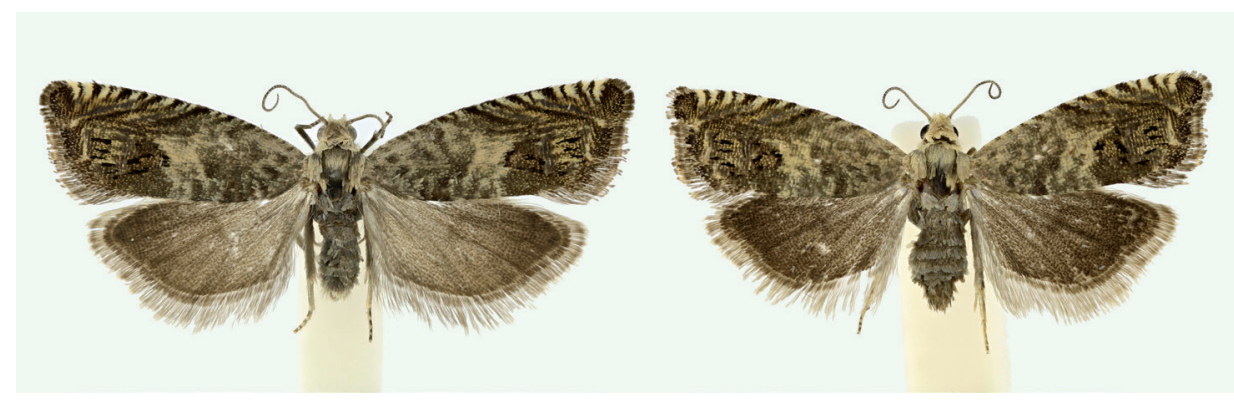

Figs 18-19. Cydia ilipulana (Walsingham, 1903), Milovice. Left: Male (11.5 mm). Right: Female (10 mm).

\section{Comments on some published records}

The occurrence data of more species from the Czech fauna of Lepidoptera are based only on a single record. Sometimes it is possible to verify the species identity if a voucher specimen is avalaible (e.g. Eulamprotes libertinella (Zeller, 1872), see Liška et al. 2015). Sometimes the doubts may persist even if the identification is clearly correct but a confusion in labelling can not be excluded (e.g. Pyrausta obfuscata (Scopoli, 1763) and P. coracinalis Leraut, 1982 in Bohemia, see Povolný \& Králíček 1984, Povolný \& Marek 2001). Among such uncertain cases we classify also the recently published record of Epichnopterix ardua Mann, 1867.

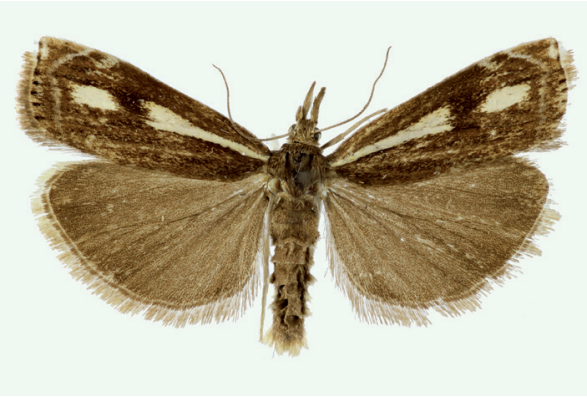

Fig. 20. Crambus heringiellus Herrich-Schäffer, 1848 , Staré Splavy $(20 \mathrm{~mm})$. 
published by Arnscheid \& Weidlich (2017) from the Králický Sněžník Mt. The sacs of related taxa are very similar and easily confusable. Therefore we accept this published record with this objection. Similarly, the occurrence of Rebelia kruegeri Turati, 1915 in the Czech Republic is based only on the records from Pouzdřany in southern Moravia published by Sitek (2013). However, Rebelia specimens from this locality were identified as $R$. sapho (Millière, 1864) by other lepidopterologists (J. Liška coll., J. Uřičář, pers. comm.), and their identification corresponds to Arnscheid \& Weidlich (2017). Thus, also in this case we accept $R$. kruegeri in the Czech checklist with an objection, and the records published by Sitek (2013) require a revision. On the other hand we incline to leave Rebelia bavarica Wehrli, 1926 as a part of Czech fauna due still not completely resolved taxonomical position of Czech individuals (cf. Arnscheid \& Weidlich 2017).

It is also worth mentioning the published or unpublished records of several taxa of which the species identity is still not clear or completely resolved, and therefore they are not listed in the current version of the Czech checklist. One so far undescribed species was published already nearly twenty years ago as „Monochroa sp. 1“ from southern Moravia (Elsner et al. 1999) and is still awaiting its description. Some additional taxa were most likely described

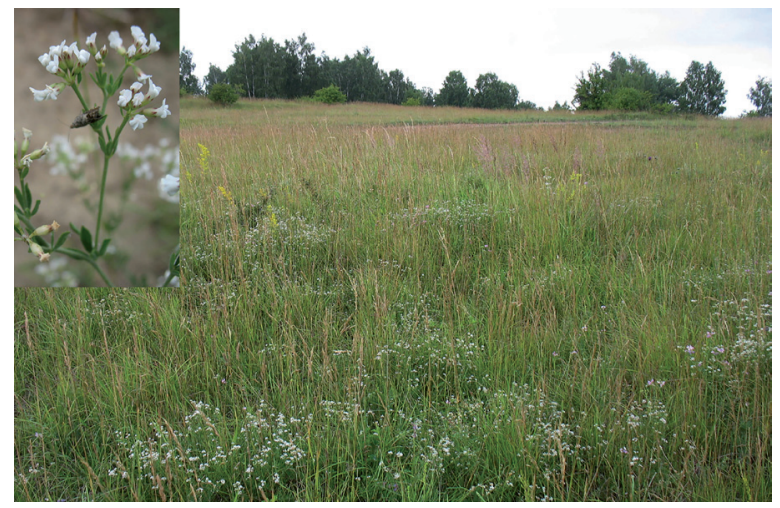

Figs 21-22. Milovice, the habitat of Coleophora bilineatella, $C$. oriolella, Syncopacma albifrontella and Cydia ilipulana. In the upper left corner: Detail of Dorycnium herbaceum with the adult of C. ilipulana.

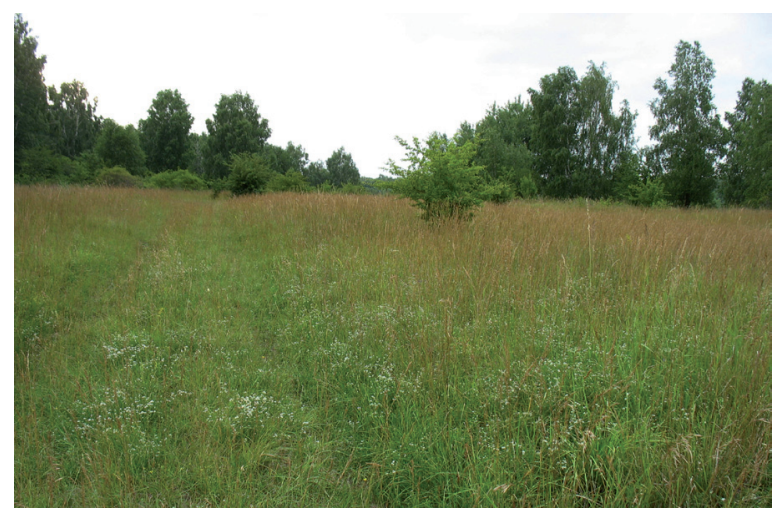
but due to the absence of a taxonomical revision they are difficult to identify reliably. This is mainly the case of some Pelochrista and Eucosma species with the occurrence reported from some neighbouring countries (e.g. Pelochrista modicana (Zeller, 1847)). The species P. modica$n a$ or P. medullana (Staudinger, 1879) were mentioned in previous Bohemian and Moravian checklists but later they were rejected as a misidentification. Actually at least one Pelochrista species, in this moment without a reliable identification, occurs here currently. Similarily we are aware of the occurrence of several other species of Lepidoptera that are currently not listed from our territory due to lack of revision works and persisting taxonomical questions. This includes for example some taxa close to Eucosma aspidiscana (Hübner, [1817]), or E. metzneriana (Treitschke, 1830).

Fig. 23. Milovice, meadow with Dorycnium herbaceum. 
The following species should be removed from the updated Czech checklist

\begin{tabular}{|l|l|}
\hline Species & Correct status \\
\hline Monochroa suffusella (Douglas, 1850) & Monochroa arundinetella (Boyd 1857) $^{1}$ \\
\hline Ephestia unicolorella Staudinger, 1881 & Ephestia woodiella Richards et Thomson, 1932 \\
\hline Agonopterix rotundella (Douglas, 1846) & Agonopterix medelichensis Buchner, 2015 \\
\hline Coleophora kroneella Fuchs, 1899 & Coleophora genistae Stainton, 1857 \\
\hline Coleophora chamaedriella Bruand, 1852 & Coleophora mareki Tabell \& Baldizzone, 2014 \\
\hline Acrobasis glaucella Staudinger, 1859 & Acrobasis fallouella (Ragonot, 1871) \\
\hline Entephria nobiliaria (Herrich-Schäffer, 1852) & Entephria flavicinctata (Hübner, 1813) \\
\hline
\end{tabular}

${ }^{1}$ this correction applies only to the Moravian checklist

\section{Comments on Lepidoptera species closely associated with Dorycnium herbaceum in Bohemia}

The occurrence of Dorycnium herbaceum Vill. in Bohemia is considered secondary (Slavík 1995, Kubát et al. 2002). However, recent records of three Lepidoptera species trophically closely associated with this plant were published from the surroundings of Milovice in central Bohemia (Liška et al. 2018, and this paper). These species, namely Coleophora bilineatella, C. oriolella and Cydia ilipulana, are monophagous (in Moravia, their larvae develop on Dorycnium germanicum (Gremli) Rikli) or oligophagous (C. oriolella develops also on Lotus and Securigera varia). All mentioned species are very rare and local in southern Moravia whereas they were not mentioned from Bohemia to date. They were most probably overlooked due to their small size and rather a lower affinity to light sources (they were collected mainly in the daytime). Their possible introduction to Bohemia is unlikely, moreover, C. ilipulana was recorded from here already more than 25 years ago. Therefore we consider also the occurrence of $D$. herbaceum in Milovice as autochtonous.

\section{Acknowledgements}

The authors thank to Peter Buchner (Austria) for the identification of the species Agonopterix paraselini. Petr Heřman (Křivoklát, Czech Republic) kindly improved the English of the final version of the manuscript. We are also indebted to Zděněk Laštůvka and Josef Jaroš for useful comments to the text. This work was financially supported by the Ministry of Culture of the Czech Republic (DKRVO 2018/12, National Museum, 00023272) (J. Šumpich) and the Ministry of Agriculture (MZE-RO0118) (J. Liška).

\section{References}

Agassiz D., 1978: Five introduced species, including one new to science, of China Mark Moths (Lepidoptera: Pyralidae) new to Britain. - Entomologist's Gazette 29: 117-127.

Arnscheid W.R. \& Weidlich M., 2017: Psychidae. - In: Karsholt O., Mutanen M. \& M. Nuss [ed.]: Microlepidoptera of Europe. Volume 8: 1-423. Leiden \& Boston: Brill.

Baldizzone G. \& der Wolf H., 2013: Fauna Europaea: Coleophoridae. In: Karsholt O. \& Nieukerken E.J. van: Fauna Europaea: Lepidoptera, Moths. Fauna Europaea version 2017.06 - https://fauna-eu.org [Accesses on 16 July 2018.]

Bauer J., 1927: Beitrag zur Lepidopterenfauna der Kleinen Karpathen, der Ungebung von Hainburg, Theben und Preszburg. - Lepidopterologische Rundschau 1: 165-167. 
Bouma M. \& Švarc J., 2017: Faunistic records from the Czech Republic - 408. - Klapalekiana 53: 6.

Buchner P., 2015: Two new species of Agonopterix (Depressariidae, Lepidoptera) from Europe. - Zootaxa 3986, 1: 101-114. https://doi.org/10.11646/zootaxa.3986.1.5

Buchner P., 2017: Redescription of Agonopterix selini (Heinemann, 1870) with description of Agonopterix lessini sp.n. and Agonopterix paraselini sp.n. (Lepidoptera, Gelechoidea). - Gortania 38: 71-101.

Buchner P. \& Šumpich J., in press: Faunistic records of Agonopterix and Depressaria from continental Spain, and updated checklist (Lepidoptera, Depressariidae). - SHILAP Revista de Lepidopterologia.

Dvořák I., 2017: Motýli národní přírodní památky Švařec. - Jihlava: Pobočka České společnosti ornitologické na Vysočině, 190 pp.

Elsner G., Huemer P. \& Tokár Z., 1999: Die Palpenmotten (Lepidoptera, Gelechiidae) Mitteleuropas. Bestimmung, Verbreitung, Flugstandort, Lebensweise der Raupen. Bratislava: František Slamka, 208 pp.

Fibiger M. \& Hacker H., 2007: Amphipyrinae, Condicinae, Eriopinae, Xyleninae. Noctuidae Europaeae, Vol. 9. - Sorø, Denmark: Entomological Press, 410 pp.

Fibiger M. \& Skule B., 2013: Fauna Europaea: Noctuidae. In: Karsholt O. \& Nieukerken E.J. van: Fauna Europaea: Lepidoptera, Moths. Fauna Europaea version 2017.06. - https://faunaeu.org [accesses on 16 July 2018]

Gaedike R., 2015: Tineidae 1 (Dryadaulinae, Hapsiferinae, Euplocaminae, Scardiinae, Nemapogoninae and Meessiinae). In: Nus M., Karsholt 0. \& Huemer P. [edit.]: Microlepidoptera of Europe. Volume 7: 1-308; Brill, Leiden \& Boston.

Gaedike R. \& Mally R., 2011: On the taxonomic status of Cephimallota angusticostella (Zeller) and C. crassiflavella Bruand (Tineidae). - Nota lepidopterologica 34: 115-130.

Gaedike R., Nuss M., Steiner A. \& Trusch R. , 2017: Verzeichnis der Schmetterlinge Deutschlands (Lepidoptera). 2. überarbeitete Auflage. - Entomologische Nachrichten und Berichte (Dresden) 21: 1-362.

Goater B., Ronkay L. \& Fibiger M., 2003: Catocalinae \& Plusiinae. Noctuidae Europaeae. Vol. 10. - Sorø: Entomological Press, 452 pp.

Gregersen K. \& Karsholt O., 2017: Taxonomic confusion around the Peach Twig Borer, Anarsia lineatella Zeller, 1839, with description of a new species (Lepidoptera, Gelechiidae). Nota Lepidopterologica 40: 65-85.

Gregor F. \& Povolný D., 1949: Další faunisticky významné a nové nálezy motýlů z Moravy. Časopis Československé společnosti entomologické 46: 1-2.

Hrubý K., 1964: Prodromus lepidopter Slovenska. Prodromus lepidopterorum Slovaciae. Bratislava: SAV, $962 \mathrm{pp}$.

Huemer P., 2013: Studiohefte 12. Die Schmetterlinge Österreichs (Lepidoptera). Systematische und faunistische Checkliste. - Tiroler Landesmuseen Betriebsgesellschaft m. b. H., Innsbruck, 304 pp. (in German, English abstract).

Jirgl T., 2015: Faunistic records from the Czech Republic - 378. - Klapalekiana 51: 48.

Karsholt O., 2013: Fauna Europaea: Gelechiidae. In: Karsholt O. \& Nieukerken E.J. van: Fauna Europaea: Lepidoptera, Moths. Fauna Europaea version 2017.06. - https://fauna-eu.org [accesses on 16 July 2018]

Komínková J. \& Šefrová H., 2014: Faunistic records from the Czech Republic - 356. Klapalekiana 50: 60.

Kubát K., Hrouda L., Chrtek J. jr., Kaplan Z., Kirschner J. \& Štěpánek J. [eds.], 2002: Klíč ke květeně České republiky. - Praha: Academia, 927 pp.

Krampl F., Marek J. \& Samec M., 2014: Faunistic records from the Czech Republic - 360. Klapalekiana 50: 109-110.

Krušek K. \& Soldát M., 1980: Motýlí Fauna Karlštejnská - 2. část (Die Schmetterlingsfauna der Gegend von Karlštejn -Teil 2). - Bohemia centralis 9: 7-26. 
Kuras T. \& Mazalová M., 2010: Motýli (Lepidoptera) Př́rodní rezervace Suchá Dora a jejího okolí (Oderské vrchy). (Butterflies (Lepidoptera) of the Suchá Dora Nature Reserve and its surroundings (Oderské vrchy Hills)). - Acta Musei Beskidensis 2: 117-137.

Laštůvka Z. (ed.), 1998: Seznam motýlů České a Slovenské republiky (Insecta, Lepidoptera). (Checklist of Lepidoptera of the Czech and Slovak Republics (Insecta, Lepidoptera)) Konvoj, Brno, 118 pp.

Laštůvka Z. \& Marek J., 2002: Motýli (Lepidoptera) Moravského krasu. Diversita, společenstva a ochrana. Lepidoptera of the Moravian Karst. Diversity, communities and protection. Blansko: Korax, 124 pp.

Laštůvka Z., Elsner V., Gottwald A., Janovský M., Liška J., Marek J. \& Povolný D., 1993: Katalog motýlů moravskoslezského regionu. Katalog von Faltern der mährisch-schlesischen Region. (Lepidoptera). - Brno: Agronomická fakulta Vysoké školy zemědělské v Brně, $130 \mathrm{pp}$.

Laštůvka Z. \& Liška J., 2011: Komentovaný seznam motýlů České republiky. Annotated checklist of moths and butterflies of the Czech Republic (Insecta: Lepidoptera). - Brno: Biocont Laboratory, 148 pp.

Liška J., 2015: Význačné druhy hmyzu Českého krasu: motýl plochuška Depressaria floridella Mann, 1864 (Lepidoptera: Elachistidae) (Significant insect species of the Bohemian Karst: depressariid moth Depressaria floridella Mann, 1864 (Lepidoptera: Elachistidae)). - Fragmenta Ioannea Collecta 21: 27-32.

Liška J., Šumpich J., Elsner G., Marek J., Laštůvka Z., Skyva J., Žemlička M., Laštůvka A., Dvořák I., Sitek J., Jirgl T., Knížek M., Uřičář J. \& Kuras T., 2015: Faunistic records from the Czech Republic - 388. - Klapalekiana 51: 239-250.

Liška J., Šumpich J., Laštůvka A., Elsner G., Žemlička M., Skyva J., Černý J., Jaroš J., Říha R., Kula E., Laštůvka Z., Vávra J., Němý J., Bělín V. \& Bezděk M., 2014: Faunistic records from the Czech Republic - 361. - Klapalekiana 50: 111-120.

Liška J., Vávra J., Laštůvka A., Jaroš J., Šumpich J., Uřičář J., Bešta L., Marek J., Skyva J., Holomek J., Kula E., Bešta M., Elsner G., Vysoký V., Žemlička M., Černý J., Richter I., Gottwald A., Laštůvka Z., Jirgl T. \& Heřman P., 2018: Faunistic records from the Czech Republic. Klapalekiana 54.

Liška J., Vávra J., Petrů M., Králíček M., Laštůvka A., Laštůvka Z., Marek J., Šumpich J. \& Uřičář J., 2008: Faunistic records from the Czech Republic - 262. - Klapalekiana 44: 289-292.

Němý J., 2012: Dahlica lazuri a D. wockii - nové druhy entomofauny v České republice a na Slovensku (Lepidoptera: Psychidae). - Folia faunistica Slovaca 17: 197-200.

Němý J., 2016: Faunistic records from the Czech Republic - 402. - Klapalekiana 52: 97-98.

Nickerl 0., 1906: Beiträge zur Insekten-Fauna Böhmens. III. Die Zünsler Böhmens (Pyralidae).

- Prag: Verlag der Gesellschaft für Physiokratie, 35 pp.

Nickerl O., 1908: Beiträge zur Insekten-Fauna Böhmens VI. Die Motten Böhmens (Tineen). Verlag der Gesellschaft für Physiokratie, Prag, $161 \mathrm{pp}$.

Novák I. \& Liška J. (eds.), 1997: Katalog motýlů (Lepidoptera) Čech. Katalog der Falter (Lepidoptera) Böhmens. - Klapalekiana 33 (Supplementum): 1-159.

Novák J. \& Beneš J. 2016: Faunistic records from the Czech Republic - 406. - Klapalekiana 52: 105.

Pastorális G., Elsner G., Kopeček F., Kosorín F., Laštůvka A., Lendel A., Liška J., Němý J., Richter I., Štefanovič R., Šumpich J. \& Tokár Z., 2013: Štrnást' nových druhov motýlov (Lepidoptera) pre faunu Slovenska. - Folia faunistica Slovaca 18: 1-12.

Povolný D. \& Gregor F., 1948: Zajímaví příslušníci xerotermní biocenosy z Mohelenské stepi. - Sborník Vysoké školy zemědělské v Brně 34: 6-12.

Povolný D. \& Králíček M. 1984: On Brachodes pumila (Ochsenheimer, 1808) and Synanthedon danubicus (Králíček, 1975) in Czechoslovakia (Lepidoptera, Sesioidea). - Acta Universitatis Agriculturae, Facultas Agronomica 32, 3: 93-104.

Povolný D. \& Marek J., 2001: A record of Pyrausta coracinalis (Lepidoptera: Pyralidae) from 
Bohemia and several considerations on the alpine insect element in the Bohemian Karst. - Klapalekiana 37: 49-52.

Sitek J., 2013: Faunistic records from the Czech Republic - 348. - Klapalekiana 49: 109-110. Sitek J., 2015: Faunistic records from the Czech Republic - 389. - Klapalekiana 51: 251-252. Sitek J. \& Vacula D., 2014: Faunistic records from the Czech Republic - 371. - Klapalekiana 50: 255-256.

Skala H., 1912-1913: Die Lepidopterenfauna Mährens. Verhandlungen des naturforschenden Vereines in Brünn 50 (1912): 63-241; 51 (1913): 116-377.

Skala H., 1931: Zur Lepidopterenfauna Mährens und Schlesiens. - Acta Mus. Moraviensis 30 (Supplementum): 1-197.

Slavík B. [ed.], 1995: Květena České republiky 4. - Praha, Academia, 529 pp.

Sterneck J., 1929: Prodromus der Schmetterlingsfauna Böhmens. - Karlsbad: Jacob Sterneck, 297 pp.

Sterneck J. \& Zimmermann F., 1933: Prodromus der Schmetterlingsfauna Böhmens II. (Microlepidoptera). - Karlsbad: Jacob Sterneck, 168 pp.

Strnad L. \& Ekrt E., 2007: Nález nové lokality kyvoru lékařského (Asplenium ceterach, Aspleniaceae, Pteridophyta) a přehled jeho rozšíření v České republice. - Zprávy České Botanické Společnosti 42: 221-229.

Šumpich J., 2011a: Motýli národních parků Podyjí a Thayatal. Die Schmetterlinge der Nationalparke Podyjí und Thayatal. Správa národního parku Podyjí, Znojmo, 428 s.

Šumpich J., 2011b: Motýli (Lepidoptera) údolí řeky Brtnice II. (Butterflies and moths (Lepidoptera) of Brtnice valley II). - Acta Rerum Naturalium (Jihlava) 10: 27-62.

Šumpich J., 2017: Motýli Středního Pojihlaví. Butterflies and Moths of the Middle Jihlava River Region. - Pobočka České společnosti ornitologické na Vysočině, Jihlava, 464 s.

Šumpich J. \& J. Jaroš, in press: Chrysoclista karsholti sp. n. from Turkey, and new record of Ch. germanica in central Europe (Lepidoptera: Elachistidae: Parametriotinae). - Zootaxa.

Šumpich J., Liška J., Sitek J., Marek J., Skyva J., Uřičář J., Fiala F., Jakeš J., Dvořák I., Maršík L., Potocký P., Laštůvka A., Elsner V., Laštůvka Z., Mikát M. \& Kačírek A., 2011: Faunistic records from the Czech Republic - 326. - Klapalekiana 47: 281-298.

Šumpich J. \& Skyva J., 2012: New faunistic records for a number of Microlepidoptera, including description of three new taxa from Agonoxenidae, Depressariidae, and Gelechiidae (Gelechioidea). - Nota Lepidopterologica 35: 161-179.

Šumpich J., Žemlička M. \& Dvořák I., 2013: Př́íspěvek k fauně motýlů (Lepidoptera) severních Čech - I. - Sborník Severočeského Muzea, Přírodní Vědy 31: 67-168.

Tabell J. \& Baldizzone G., 2014: Coleophora mareki Tabell \& Baldizzone, sp. n., a new coleophorid moth of the serpylletorum species-group (Lepidoptera: Coleophoridae). SHILAP Revista de Lepidopterología 42: 399-408.

Vlach V. ,1942: Nové druhy Microlepidopter pro Čechy (New Microlepidoptera for Bohemia). - Časopis České Společnosti Entomologické 39: 70-72.

Walsingham M. A., 1903: Spanish and Moorisch Micro-Lepidoptera. - Entomological Monthly Magazine 39: 209.

Zapletal M. \& Knížek J., 2016: Faunistic records from the Czech Republic - 407. - Klapalekiana 52: 106.

\section{Appendix}

Lepidoptera species not listed for the Czech Republic or for its part by Laštůvka \& Liška (2011) with their first records (B = Bohemia; M = Moravia; S - Silesia; CZ - Czech Republic; * - alien species; ${ }^{* *}$ - synanthropic or mostly synanthropic occurrence, *** - migrant; very old records are in brackets). 


\begin{tabular}{|c|c|c|c|c|c|}
\hline Species & B & $\mathbf{M}$ & $\mathbf{S}$ & $\mathbf{C Z}$ & Source \\
\hline \multicolumn{6}{|l|}{ Incurvariidae } \\
\hline Lampronia capitella (Clerck, 1759) & & M & & & $\begin{array}{l}\text { Kuras \& Mazalová (2010), Liška } \\
\text { et al. (2015) }\end{array}$ \\
\hline \multicolumn{6}{|l|}{ Psychidae } \\
\hline Dahlica charlottae (Meier, 1957) & & $\mathrm{M}$ & & & Němý (2016) \\
\hline Dahlica lazuri (Clerck, 1759) & B & M & & $\mathrm{CZ}$ & Němý (2012) \\
\hline Dahlica wockii (Heinemann, 1870) & & M & & $\mathrm{CZ}$ & $\begin{array}{l}\text { Sterneck \& Zimmermann } \\
\text { (1933), Němý (2012) }\end{array}$ \\
\hline Epichnopterix ardua Mann, 1867 & B & & & $\mathrm{CZ}$ & Arnscheid \& Weidlich (2017) \\
\hline Rebelia kruegeri Turati, 1914 & & M & & $\mathrm{CZ}$ & Sitek (2013) \\
\hline Rebelia surientella (Bruand, 1858) & & $\mathrm{M}$ & & $\mathrm{CZ}$ & Liška et al. (2014) \\
\hline \multicolumn{6}{|l|}{ Tineidae } \\
\hline Cephimallota angusticostella (Zeller, 1839) & B & & & $\mathrm{CZ}$ & $\begin{array}{l}\text { Gaedike \& Mally (2011), Liška } \\
\text { et al. (2018) }\end{array}$ \\
\hline Ischnoscia borreonella (Millière, 1874) & (B) & & & $(\mathrm{CZ})$ & Nickerl (1908) \\
\hline Monopis fenestratella (Heyden, 1863) & $\mathrm{B}$ & & & & Liška et al. (2018) \\
\hline Monopis neglecta Šumpich \& Liška, 2011 & & $\mathrm{M}$ & & $\mathrm{CZ}$ & Šumpich (2011a) \\
\hline Pelecystola fraudulentella (Zeller, 1852) & (B) & & & $(\mathrm{CZ})$ & $\begin{array}{l}\text { Sterneck \& Zimmermann } \\
(1933)\end{array}$ \\
\hline \multicolumn{6}{|l|}{ Gracillariidae } \\
\hline Caloptilia honoratella (Rebel, 1914) & $\mathrm{B}$ & & & & Liška et al. (2018) \\
\hline Caloptilia jurateae Bengtsson, 2010 & B & & $\mathrm{S}$ & $\mathrm{CZ}$ & Liška et al. $(2014,2018)$ \\
\hline Phyllocnistis asiatica Martynova, 1955 & $\mathrm{~B}$ & $\mathrm{M}$ & & $\mathrm{CZ}$ & Liška et al. (2018) \\
\hline Phyllocnistis extrematrix Martynova, 1955 & $\mathrm{~B}$ & M & & $\mathrm{CZ}$ & Liška et al. $(2014,2018)$ \\
\hline $\begin{array}{l}\text { Phyllocnistis ramulicola Langmaid et } \\
\text { Corley, } 2007\end{array}$ & B & M & & $\mathrm{CZ}$ & Liška et al. $(2014,2018)$ \\
\hline Phyllocnistis valentinensis Hering, 1936 & B & M & & $\mathrm{CZ}$ & $\begin{array}{l}\text { Pastorális et al. (2013), Liška et } \\
\text { al. (2014) }\end{array}$ \\
\hline Phyllonorycter hostis Triberti, 2007 & & M & & $\mathrm{CZ}$ & Liška et al. (2014) \\
\hline $\begin{array}{l}\text { Phyllonorycter trifoliella (Gerasimov, } \\
\text { 1933) }\end{array}$ & B & & & $\mathrm{CZ}$ & Liška et al. (2018) \\
\hline \multicolumn{6}{|l|}{ Bucculatricidae } \\
\hline $\begin{array}{l}\text { Bucculatrix humiliella Herrich-Schäffer, } \\
1855\end{array}$ & & M & & & Liška et al. (2015) \\
\hline \multicolumn{6}{|l|}{ Argyresthiidae } \\
\hline Argyresthia aurulentella Stainton, 1849 & & M & & & Liška et al. (2014) \\
\hline $\begin{array}{l}\text { Argyresthia kulfani Bengtsson et } \\
\text { Johansson, } 2012\end{array}$ & B & M & & $\mathrm{CZ}$ & Liška et al. (2018) \\
\hline $\begin{array}{l}\text { Argyresthia svenssoni Bengtsson et } \\
\text { Johansson, } 2012\end{array}$ & B & & & $\mathrm{CZ}$ & Liška et al. (2014) \\
\hline \multicolumn{6}{|l|}{ Plutellidae } \\
\hline $\begin{array}{l}\text { Rhigognostis schmaltzella (Zetterstedt, } \\
\text { 1839) }\end{array}$ & B & & & $\mathrm{CZ}$ & Liška et al. (2018) \\
\hline \multicolumn{6}{|l|}{ Glyphipterigidae } \\
\hline Digitivalva valeriella (Snellen, 1878) & & M & & $\mathrm{CZ}$ & Liška et al. (2014) \\
\hline Ypsolophidae & & & & & \\
\hline
\end{tabular}




\begin{tabular}{|c|c|c|c|c|}
\hline Ypsolopha chazariella (Mann, 1866) & B & & & Liška et al. (2014) \\
\hline \multicolumn{5}{|l|}{ Acrolepiidae } \\
\hline Acrolepia autumnitella Curtis, 1838 & & M & & Liška et al. (2015) \\
\hline \multicolumn{5}{|l|}{ Blastobasidae } \\
\hline $\begin{array}{l}\text { Blastobasis pannonica Šumpich \& Liška, } \\
2011\end{array}$ & & M & $\mathrm{CZ}$ & Šumpich (2011) \\
\hline Tecmerium perplexum (Gozmány, 1957) & & $\mathrm{M}$ & $\mathrm{CZ}$ & Liška et al. (2014) \\
\hline \multicolumn{5}{|l|}{ Oecophoridae } \\
\hline Batia lunaris (Haworth, 1828) & $\mathrm{B}$ & & $\mathrm{CZ}$ & Liška et al. (2018) \\
\hline \multicolumn{5}{|l|}{ Lypusidae } \\
\hline Agnoea synchrozella (Jäckh, 1959) & $\mathrm{B}$ & & $\mathrm{CZ}$ & Liška et al. (2018) \\
\hline \multicolumn{5}{|l|}{ Elachistidae } \\
\hline Elachista consortella Stainton 1851 & & M & & Liška et al. (2015) \\
\hline Elachista scirpi Stainton, 1887 & & M & $\mathrm{CZ}$ & Liška et al. (2015) \\
\hline Chrysoclista gabretica Šumpich, 2012 & B & & $\mathrm{CZ}$ & Šumpich \& Skyva (2012) \\
\hline $\begin{array}{l}\text { Chrysoclista germanica Šumpich et } \\
\text { Huemer, } 2016\end{array}$ & B & & $\mathrm{CZ}$ & Šumpich \& Jaroš (in press) \\
\hline \multicolumn{5}{|l|}{ Depressariidae } \\
\hline Agonopterix bipunctosa (Curtis, 1850) & & M & $\mathrm{CZ}$ & Sitek \& Vacula (2014) \\
\hline Agonopterix medelichensis Buchner, 2015 & B & M & $\mathrm{CZ}$ & this paper \\
\hline Agonopterix paraselini Buchner, 2017 & & M & $\mathrm{CZ}$ & this paper \\
\hline Depressaria bupleurella Heinemann, 1870 & B & & & Liška et al. (2018) \\
\hline Depressaria floridella (Mann, 1864) & $\mathrm{B}$ & M & $\mathrm{CZ}$ & $\begin{array}{l}\text { Šumpich et al. (2013), Liška et } \\
\text { al. (2015) }\end{array}$ \\
\hline Depressaria libanotidella Schläger, 1849 & (B) & & & Liška et al. (2018) \\
\hline \multicolumn{5}{|l|}{ Coleophoridae } \\
\hline $\begin{array}{l}\text { Coleophora aleramica Baldizzone et } \\
\text { Stübner, } 2007\end{array}$ & B & M & $\mathrm{CZ}$ & Liška et al. (2018), this paper \\
\hline Coleophora bilineatella Zeller, 1849 & $\mathrm{~B}$ & & & this paper \\
\hline Coleophora bornicensis Fuchs, 1886 & & M & $\mathrm{CZ}$ & Liška et al. (2018) \\
\hline Coleophora frankii Schmidt, 1886 & & M & & Liška et al. (2015) \\
\hline Coleophora glaseri Toll, 1961 & $\mathrm{~B}$ & & & Krampl et al. (2014) \\
\hline Coleophora hackmani (Toll, 1953) & & $\mathrm{M}$ & $\mathrm{CZ}$ & Sitek (2015) \\
\hline Coleophora chalcogrammella Zeller, 1839 & & M & & Liška et al. (2014) \\
\hline $\begin{array}{l}\text { Coleophora mareki Tabell \& Baldizzone, } \\
2014\end{array}$ & B & M & $\mathrm{CZ}$ & Tabell \& Baldizzone (2014) \\
\hline Coleophora oriolella Zeller, 1849 & $\mathrm{~B}$ & & & this paper \\
\hline Coleophora paramayrella Nel, 1993 & B & M & & Liška et al. (2015) \\
\hline Coleophora scabrida Toll, 1959 & B & M & $\mathrm{CZ}$ & $\begin{array}{l}\text { Krampl et al. (2014), Šumpich } \\
(2017)\end{array}$ \\
\hline Coleophora subula (Falkovitsh, 1993) & & $\mathrm{M}$ & $\mathrm{CZ}$ & Liška et al. (2018) \\
\hline Coleophora variicornis Toll, 1952 & B & & & Liška et al. (2018) \\
\hline \multicolumn{5}{|l|}{ Scythrididae } \\
\hline Scythris buszkoi Baran, 2004 & & M & $\mathrm{CZ}$ & Sitek \& Vacula (2014) \\
\hline
\end{tabular}




\begin{tabular}{|c|c|c|c|c|c|}
\hline Scythris fuscoaenea (Haworth, 1828) & & $\mathrm{M}$ & & & Liška et al. (2018) \\
\hline \multicolumn{6}{|l|}{ Gelechiidae } \\
\hline $\begin{array}{l}\text { Anarsia innoxiella Gregersen \& Karsholt, } \\
2017\end{array}$ & B & $\mathrm{M}$ & & $\mathrm{CZ}$ & $\begin{array}{l}\text { Gregersen \& Karsholt (2017), } \\
\text { Šmpich (2017) }\end{array}$ \\
\hline Caryocolum pullatella (Tengström, 1848) & & M & & $\mathrm{CZ}$ & Šumpich (2017) \\
\hline * Coleotechnites piceaella (Kearfott, 1903) & $\mathrm{B}$ & & & & Liška et al. (2014) \\
\hline Ephysteris diminutella (Zeller, 1847) & & M & & $\mathrm{CZ}$ & Liška et al. (2014) \\
\hline Eulamprotes libertinella (Zeller, 1872) & (B) & & & $(\mathrm{CZ})$ & Liška et al. (2015) \\
\hline Monochroa arundinetella (Boyd 1857) & & M & & & Liška et al. (2015) \\
\hline Monochroa niphognatha (Gozmány, 1953) & & M & & $\mathrm{CZ}$ & Sitek (2015) \\
\hline Monochroa rectifasciella Fuchs, 1902 & & M & & $\mathrm{CZ}$ & Šumpich (2011a) \\
\hline Ptocheuusa paupella (Zeller, 1047) & & M & & $\mathrm{CZ}$ & Liška et al. (2018) \\
\hline Scrobipalpa hyoscyamella (Stainton, 1869) & (B) & & & (CZ) & Liška et al. (2015) \\
\hline $\begin{array}{l}\text { Syncopacma albifrontella (Heinemann, } \\
1870 \text { ) }\end{array}$ & B & & & & this paper \\
\hline \multicolumn{6}{|l|}{ Epermeniidae } \\
\hline Epermenia profugella (Stainton, 1856) & & $\mathrm{M}$ & & & Liška et al. (2014) \\
\hline \multicolumn{6}{|l|}{ Tortricidae } \\
\hline Acleris lacordairana (Duponchel, 1836) & & M & & $\mathrm{CZ}$ & Liška et al. (2014) \\
\hline Acleris quercinana (Zeller, 1849) & & M & & $\mathrm{CZ}$ & Sitek (2013) \\
\hline Argyroploce concretana (Wocke, 1862) & $\mathrm{B}$ & & & $\mathrm{CZ}$ & Liška et al. (2018) \\
\hline Bactra robustana (Christoph, 1872) & B & M & & $\mathrm{CZ}$ & Liška et al. (2015) \\
\hline Bactra suedana (Bengtsson, 1990) & & M & & $\mathrm{CZ}$ & Němý (2016) \\
\hline Celypha rosaceana Schläger, 1847 & & M & & & Komínková \& Šefrová (2014) \\
\hline Cydia exquisitana (Rebel, 1899) & & M & & $\mathrm{CZ}$ & Liška et al. (2015) \\
\hline Cydia ilipulana (Walsingham, 1903) & $\mathrm{B}$ & & & & Liška et al. (2018), this paper \\
\hline Epinotia cinereana Haworth, 1811 & $\mathrm{~B}$ & $\mathrm{M}$ & & $\mathrm{CZ}$ & Liška et al. (2014) \\
\hline Eugnosta lathoniana (Hübner, [1800]) & & $\mathrm{M}$ & & $\mathrm{CZ}$ & Šumpich et al. (in prep.) \\
\hline $\begin{array}{l}\text { Gynnidomorpha minimana (Caradja, } \\
\text { 1916) }\end{array}$ & & M & & $\mathrm{CZ}$ & Liška et al. (2014) \\
\hline Olethreutes subtilana (Falkovitsh, 1959) & B & & & $\mathrm{CZ}$ & Liška et al. (2014) \\
\hline Phalonidia contractana (Zeller, 1847) & B & & & & Liška et al. (2018) \\
\hline Phalonidia udana Guenée, 1845 & & $\mathrm{M}$ & & $\mathrm{CZ}$ & Liška et al. (2014) \\
\hline \multicolumn{6}{|l|}{ Brachodidae } \\
\hline Brachodes pumila (Ochsenheimer, 1808) & (B) & & & $\mathrm{CZ}$ & this paper \\
\hline \multicolumn{6}{|l|}{ Sesiidae } \\
\hline Synanthedon soffneri Špatenka, 1983 & & M & & & Liška et al. (2014) \\
\hline \multicolumn{6}{|l|}{ Lycaenidae } \\
\hline *** Cacyreus marshalli Butler, 1898 & & & S & $\mathrm{CZ}$ & Novák \& Beneš (2016) \\
\hline \multicolumn{6}{|l|}{ Nymphalidae } \\
\hline Limenitis reducta Staudinger, 1901 & (B) & & & $(\mathrm{CZ})$ & this paper \\
\hline Pyralidae & & & & & \\
\hline
\end{tabular}




\begin{tabular}{|c|c|c|c|c|c|}
\hline Acrobasis dulcella (Zeller, 1848) & (B) & & & (CZ) & Liška et al. (2015) \\
\hline Acrobasis fallouella (Ragonot, 1871) & & M & & $\mathrm{CZ}$ & Skala (1931), Šumpich (2017) \\
\hline Aglossa caprealis (Hübner, [1809]) & & M & & $\mathrm{CZ}$ & Liška et al. (2015) \\
\hline ** Cadra figulilella (Gregson, 1871) & & M & & & $\begin{array}{l}\text { Sitek \& Vacula (2014), Liška et } \\
\text { al. (2015) }\end{array}$ \\
\hline $\begin{array}{l}\text { Delplanqueia inscriptella (Duponchel, } \\
1836 \text { ) }\end{array}$ & B & M & & $\mathrm{CZ}$ & Šumpich (2017) \\
\hline ** Endotricha kuznetzovi Whalley, 1963 & & & S & $\mathrm{CZ}$ & Sitek (2015) \\
\hline $\begin{array}{l}\text { Ephestia woodiella Richards et Thomson, } \\
1932\end{array}$ & B & M & & $\mathrm{CZ}$ & Liška et al. (2018) \\
\hline Phycitodes inquinatella (Ragonot, 1887) & & M & & $\mathrm{CZ}$ & Liška et al. (2014) \\
\hline${ }^{* *}$ Pyralis lienigialis Zeller, 1843 & & M & & $\mathrm{CZ}$ & Liška et al. (2015) \\
\hline Synaphe antennalis (Fabricius, 1794) & (B) & & & & Liška et al. (2015) \\
\hline \multicolumn{6}{|l|}{ Crambidae } \\
\hline Agriphila tolli (Błeszyński, 1952) & $\mathrm{B}$ & & & & Liška et al. (2015) \\
\hline *Cydalima perspectalis (Walker, 1859) & B & M & & $\mathrm{CZ}$ & $\begin{array}{l}\text { Šumpich (2011a), Liška et al. } \\
\text { (2015) }\end{array}$ \\
\hline Mecyna lutealis (Duponchel, 1833) & B & & & $\mathrm{CZ}$ & $\begin{array}{l}\text { Nickerl (1906), Liška et al. } \\
\text { (2014) }\end{array}$ \\
\hline Pyrausta obfuscata (Scopoli, 1763) & & M & & & Liška et al. (2018) \\
\hline${ }^{* * *}$ Spoladea recurvalis (Fabricius, 1775 ) & & $\mathrm{M}$ & & $\mathrm{CZ}$ & Liška et al. (2018) \\
\hline${ }^{*}$ Sufetula sp. & B & & & $\mathrm{CZ}$ & Šumpich (in prep.) \\
\hline \multicolumn{6}{|l|}{ Geometridae } \\
\hline Cyclophora puppillaria (Hübner, 1799) & $\mathrm{B}$ & & & $\mathrm{CZ}$ & Jirgl (2015) \\
\hline Eilicrinia trinotata (Metzner, 1845) & & M & & $\mathrm{CZ}$ & Liška et al. (2018) \\
\hline${ }^{*}$ Stegania trimaculata (de Villers, 1789) & B & & & $\mathrm{CZ}$ & Zapletal \& Knížek (2016) \\
\hline \multicolumn{6}{|l|}{ Erebidae } \\
\hline *** Dysgonia algira (Linnaeus, 1767) & $\mathrm{B}$ & & & & Bouma \& Švarc (2017) \\
\hline \multicolumn{6}{|l|}{ Noctuidae } \\
\hline Eucarta amethystina (Hübner, 1803) & & M & & $\mathrm{CZ}$ & Liška et al. (2014) \\
\hline $\begin{array}{l}{ }^{* * *} \text { Heliothis nubigera Herrich-Schäffer, } \\
1851\end{array}$ & & M & & & Sitek (2013) \\
\hline Plusidia cheiranthi (Tauscher, 1809) & (B) & & & $(\mathrm{CZ})$ & Goater et al. (2003) \\
\hline Callopistria latreillei (Duponchel, 1827) & & $\mathrm{M}$ & & $\mathrm{CZ}$ & this paper \\
\hline Polyphaenis sericata (Esper, 1787) & $\mathrm{B}$ & & & & Krampl et al. (2014) \\
\hline Senta flammea (Curtis, 1828) & (B) & M & & $\mathrm{CZ}$ & $\begin{array}{l}\text { Sterneck (1929), Liška et al. } \\
\text { (2018) }\end{array}$ \\
\hline
\end{tabular}

